\title{
STRUKTUR KALIMAT BAHASA BURU DESA FAKAL KECAMATAN FENAFAFAN KABUPATEN BURU SELATAN
}

\author{
Elda Sasake \\ Heppy Leunard Lelapary \\ Elsa Latupeirissa
}

\begin{abstract}
ABSTRAK: Penelitian ini adalah penelitian kualitatif deskritif yang bertujuan untuk mendeskripsikan struktur kalimat bahasa Buru masyarakat Desa Fakal Kecamatan Fenafafan Kabupaten Buru Selatan. Metode yang digunakan adalah metode observasi. Bahasa Buru merupakan salah satu bahasa daerah yang ada di Indonesia dan masih digunakan oleh masyarakat di Kepulauan Buru Provinsi Maluku. Struktur kalimat bahasa Buru tidak berbeda jauh dengan struktur kalimat bahasa Indonesia, dalam struktur penulisan bahasa Buru juga terdapat subjek, predikat, objek, dan keterangan yang umumnya ditemukan pada penulisan bahasa Indonesia. Bahasa Buru mempunyai unsur kebahasaan seperti unsur pada bahasa Indonesia yaitu struktur bunyi bahasa, struktur kata, struktur kalimat, dan makna.
\end{abstract}

Kata kunci: struktur kalimat, bahasa Buru. 


\title{
STRUCTURE OF SENTENCE VOCATIONAL SCHOOL OF VOCATIONAL SCHOOL OF FAKAL DISTRICT, FENAFAFAN, BURU SELATAN DISTRICT
}

\author{
Elda Sasake \\ Heppy Leunard Lelapary \\ Elsa Latupeirissa
}

\begin{abstract}
This research is a descriptive qualitative study that aims to describe the sentence structure of the Buru language in Fakal Village, Fenafafan District, South Buru Regency. The method used is the observation method. Buru language is one of the regional languages in Indonesia and is still used by people in the Buru Islands, Maluku Province. Buru language sentence structure is not much different from the Indonesian sentence structure, in the Buru language sentence structure also contains subjects, predicates, objects, and information found found when using Indonesian. Buru language does not have language as it is not in Indonesian, namely language structure, word structure, sentence structure, and meaning.
\end{abstract}

Keywords: structure of sentences, Buru language. 


\section{A. PENDAHULUAN}

Bahasa adalah sistem lambang bunyi yang digunakan oleh anggota masyarakat untuk bekerja sama, berinteraksi, dan mengidentifikasikan diri (Kridalaksana, 2008: 24). Hal tersebut yang menjadi alasan bahasa merupakan alat komunikasi yang penting. Bahasa mempunyai fungsi sebagai alat pertukaran informasi berkaitan dengan bahasa sebagai alat untuk berbagi informasi.

Sehubungan dengan fungsi bahasa, Bahasa daerah merupakan salah satu unsur budaya harus dijaga kelestariannya karena bahasa daerah menunjukan keragaman dan sekaligus kekayaan bangsa yang tidak ternilai harganya. Bahasa Buru merupakan salah satu bahasa daerah yang ada di Indonesia dan masih digunakan oleh masyarakat di Kepulauan Buru Provinsi Maluku. Berdasarkan hasil penelitian diketahui bahwa penduduk pulau Buru menggunakan bahasa Buru dalam setiap aktivitas sehari-hari, termasuk juga masyarakat desa Fakal, kecamatan Fenafafan kabupaten Buru Selatan.

Bahasa Buru pada hakikatnya sama dengan bahasa-bahasa yang lain yang mempunyai peranan penting bagi kehidupan manusia. Selain itu, bahasa Buru juga mempunyai unsur-unsur kebahasaan seperti unsur-unsur pada bahasa Indonesia. Adapun unsur-unsur kebahasaan tersebut terdiri atas struktur bunyi bahasa, struktur kata, struktur antarkata dalam kalimat, masalah arti atau makna. Struktur kalimat bahasa Buru dapat dilihat pada contoh berikut: 


\section{Yako ka mangkao lea-lea}

SPOK

'Saya makan singkong setiap hari'

\section{Kami foi tu waelea tifun}

SPKTKW

'Kami mandi di sungai siang hari'

Struktur kalimat tersebut adalah struktur kalimat berdasarkan fungsinya, sedangkan kalimat berikut ini adalah struktur kalimat berdasarkan kategorinya:

\section{1. $\quad$ Sira midi ktare bolatu hari minggu \\ N V FNF.Preposisi \\ 'Mereka bermain sepak bola di hari minggu'}

Dari contoh tersebut diketahui bahwa struktur kalimat bahasa Buru tidak berbeda jauh dengan struktur kalimat bahasa Indonesia karena dalam struktur penulisan bahasa Buru juga terdapat subjek, predikat, objek, dan keterangan yang umumnya ditemukan pada penulisan bahasa Indonesia. Hal ini dapat dilihat pada contoh kalimat bahasa Buru diatas.

Bahasa Buru merupakan bahasa daerah yang layak untuk diteliti terkhususnya di desa Fakal Kecamatan Fenafafan Kabupaten Buru Selatan. Masyarakat Buru yang berdomisili di Desa Fakal masih produktif menggunakan bahasa Buru sebagai bahasa pertama untuk berkomunikasi dalam lingkungan dan untuk keperluan bersifat khusus seperti pertemuan adat hukum dan lain-lain. Jadi, bahasa Buru masih diyakini sebagai sarana komunikasi yang masih efektif dan praktis untuk menjalin kerja sama dan hubungan sosial antar penuturnya walaupun wilayah pakainya berjauhan. 
Penelitian mengenai bahasa Buru pernah dilakukan oleh Rinto Hukunala mahasiswa FKIP Program Studi Pendidikan Bahasa dan Sastra Indonesia Universitas Pattimura Ambon, dengan judul skripsi "Reduplikasi dalam Bahasa Buru di Desa Wamkana Kecamatan Namrole Kabupaten Buru Selatan Suatu Kajian Tata Bentuk” tahun 2013. Penelitian yang dilakukan oleh Rinto ini membahas tentang pengulangan kata saja.

Rumusan masalah dalam penelitian ini adalah bagaimanakah struktur kalimat bahasa Buru masyarakat Desa Fakal Kecamatan Fenafafan Kabupaten Buru Selatan?

\section{B. METODE PENELITIAN}

Penelitian ini menggunakan metode penelitian deskriptif kualitatif. Metode ini adalah metode penelitian dengan menggambarkan objek penelitian apa adanya, terutama yang berhubungan langsung dengan pengumpulan data, pengolahan data, dan penyusunan laporan hasil penelitian.

Metode deskriptif bertujuan untuk membuat deskripsi yang sistematis dan akurat mengenai data, sifat serta hubungan fenomena-fenomena yang diteliti. (Djajasudarma, 1999: 8).

Data dalam penelitian ini adalah data berupa tuturan-tuturan dalam bahasa Buru yang dituturkan oleh masyarakat di Desa Fakal Kecamatan Fenafafan Kabupaten Buru Selatan. Sumber data penelitian ini adalah informan yang mendiami Desa Fakal Kecamatan Fenafafan Kabupaten Buru Selatan, yang berjumlah 5 orang ditambah 
dengan masyarakat setempat. Data-data tersebut dikumpulkan dengan caraobservasi, wawancara, teknik catatan lapangan dan rekaman.

Setelah data dan informasi terkumpul kemudian dideskripsikan secara kualitatif dan diolah dalam bentuk data primer mengenai struktur kalimat bahasa Buru Desa Fakal Kecamatan Fenafafan Kabupaten Buru Selatan. Model analisis data dalam penelitian kualitatif ini menggunakan teknik analisis data model interaktif. Miles dan Huberman (2003: 16-20) menyatakan bahwa model ini memiliki dua ciri yang menonjol, yaitu analisis selama pengumpulan data yang berkaitan dengan struktur kalimat bahasa Buru dan analisis setelah pengumpulan data.

\section{PEMBAHASAN}

\section{Kalimat Berdasarkan Jumlah Klausa}

Berdasarkan klausanya, kalimat dapat diklasifikasi sebagai berikut;

\section{a) Kalimat Tunggal}

Kalimat tunggal dalam bahasa Buru

a. $\underline{\text { Ibu oli }}$

S P

'Ibu pulang'

Kalimat ibu oli termaksud dalam kalimat tunggal karena hanya memiliki satu klausa bebas yang berupa predikat (P) yang terdapat pada kata oli. Ibu oli di artikan dalam bahasa Indonesia yaitu ibu pulang. 


\section{b) Kalimat Majemuk}

Kalimat majemuk dalam bahasa buru

Sesak woretel, na musim, pa efilik

'Wortel itu ditanam, di panen, dan di jual'

Kalimat ini merupakan kalimat majemuk karena terdiri dari dua predikat. Sesak wortel merupakan subjek (S), na musim merupakan predikat pertama (P1), dan pa efiik merupakan predikat kedua (P2). Dalam bahasa Indonesia kalimat sesak wortel, na musim, pa efilik artinya wortel itu ditanam, di panen, dan dijual.

1) Kalimat majemuk setara

Kalimat majemuk setara dalam bahasa Buru adalah

Bapan-bapan sira iko gamdi hawa, sedangkan yako iko to pasar.

Bapak-bapak pergi ke kebun, sedangkan saya pergi ke pasar,

Kalimat ini termaksud dalam kalimat majemuk setara karena memiliki dua pokok pikiran yang kedudukannya sama atau setara. Pokok pikiran pertama terdapat pada kalimat bapan-bapan sira iko gamdi hawa yang artinya bapak-bapak pergi ke kebun dan pokok pikiran kedua terdapat pada kalimat yako iko to pasar yang artinya saya pergi ke pasar. Frasa yang menujukkan kalimat setara yaitu kata sedangkan. 
2) Kalimat Majemuk Bertingkat

Kalimat majemuk bertingkat dalam bahasa Buru Kepala kampong dena pa kami saleh labetu

'Kedatangan kepala Desa di sambut oleh warga kemarin'

Kalimat tersebut merupakan kalimat majemuk bertingkat karena memiliki kalimat tunggal yang jabatannya dapat diperluas membentuk kalimat baru. Dalam bahasa Indonesia kalimat kepala kampoeng dena pa kami saleh labetu yaitu kedatangan kepala desa disambut oleh warga kemarin. Frasa yang menunjukan kalimat majemuk bertingkat terdapat pada kata $p a$ (oleh).

\section{3) Kalimat Berdasarkan Fungsi}

Kalimat berdasarkan fungsi diklasifikasikan sebagai berikut:

a) Kalimat Berita

Kalimat berita dalam bahasa Buru yaitu:

a. Egu wortel tu mangsafut taong na da gosa gamdi taong leuk mo.

'Panen wortel dan kentang tahun ini tidak sebagus tahun kemarin'

Kalimat ini merupakan kalimat berita yang bertujuan untuk memberikan informasi tanpa adanya respon balik atas berita tersebut. Arti dari kalimat diatas dalam bahasa Indonesia adalah panen wortel dan kentang tahun ini tidak sebagus tahun kemarin. 
b) Kalimat Tanya

Kalimat tanya dalam bahasa Buru

Kain save sapan?

'Kakak beli apa?'

Kalimat diatas merupakan kalimat tanya yang bertujuan untuk mendapatkan informasi atau suatu hal. Kalimat tersebut dalam bahasa Indonesia artinya kakak beli apa.

c) Kalimat Perintah

Kalimat perinta dalam bahasa Buru

Wain rogo la beget tu supan eskolah!

'Anak-anak masuk tidur sudah, besok sekolah!

Kalimat diatas merupakan kalimat perintah yang diharkapan adanya respon berupa tindakan atau perbuatan dari orang yang diajak bicara. Kalimat-kalimat ini sering digunakan masyarakat Fakal dalam kehidupan sehari-hari mereka.Kalimat tersebut dalam bahasa Indonesia adalah anak masuk tidur sudah, besok sekolah!

d) Kalimat Seruan

Kalimat seruan dalam bahasa Buru

Besopah!

'apa kabar’ 
Kalimat teresbut merupakan kalimat seruan yang berfungsi untuk mengekspresikan perasaan pemakainya. Kalimat diatas merupakan kalimat seruan yang sering digunakan oleh masyarakat Fakal setempat, dalam percakapan seharihari.

\section{Kalimat Berdasarkan Kelengkapan Unsurnya}

a) Kalimat Lengkap

Kalimat lengkap dalam bahasa Buru adalah :

Kalau yako nangu kepeng, yako safe espatu pakae.

'Kalau saya mempunyai uang, saya akan membeli sepatu untukmu'

Kalimat ini merupakan kalimat lengkap karena terdiri dari klausa bebas. Kalimat ini merupakan kalimat lengkap majemuk karena yang mendasari kalimat sempurna adalah suatu klausa bebas. Arti dari kalimat diatas dalam bahasa Indonesia adalah kalau saya mempunyai uang, saya akan membeli sepatu untukmu.

b) Kalimat Tak Lengkap

Kalimat tak lengkap dapat diklasifikasikan sebagai berikut:

1) Kalimat Urutan

Kalimat urutan dalam bahasa Buru adalah:

Eta wain iko

'Ketika adik pergi' 
Kalimat diatas termasuk kalimat urutan karena dawali oleh kongjungsi dan memiliki klausa terikat. Kalimat tersebut artinya dalam bahasa Indonesia adalah ketika adik pergi.

2) Kalimat Sampingan

Kalimat sampingan dalam bahasa Buru adalah: yako dapak hai palekmo.

'Bahkan aku tak sempat ikut sama sekali'

Kalimat diatas tersebut merupakan kalimat sampingan yang tersusun dari kluasa terikat, yang diturunkan dari kalimat majemuk bertingkat. Dalam bahasa Indonesia artinya bahkan aku tak sempat ikut sama sekali.

\section{3) Kalimat Elips}

Kalimat elips dalam bahasa Buru adalah

Elda: iko safe?

'Elda: pergi berbelanja?'

Kalimat di atas adalah kalimat elips dalam bahasa Buru. Kalimat yang tidak memiliki struktur klausa. Kalimat iko safe merupakan kalimat yang tidak sempurna karena tidak memiliki klausa. Kalimat diatas dimaksudkan bahwa saya (elda) menanyakan seseorang yang hendak pergi. Arti dari kalimat diatas dalam bahasa Indonesia adalah Elda: pergi berbelanja? 
4) Kalimat Tambahan

1) Fulan sahet akin (kami egu wortel)

'Bulan depan (kami panen wortel)

2) Minggu sahet akin (kaim efilik ihawarlalen)

'Minggu depan (kita menjual hasil panen)

Dua kalimat di atas menjelaskan bahwa kalimat tambahan terdapat pada kalimat akhir sesudah kalimat jawaban. Contoh pertama: Kalimat (1) Fulan sahet akin (bulan depan) merupakan kalimat jawaban, sedangkan kami egu wortel (kami panen wortel) merupakan kalimat tambahan.contohKalimat (2) Minggu sahet akin (minggu depan)merupakan kalimat jawaban, sedangkan kami efilik ihawarlalen (kita menjual hasil panen) merupakan kalimat tambahan.

\section{KESIMPULAN}

Berdasarkan penelitian yang telah dilakukan disimpulkan bahwa Struktur kalimat bahasa Buru pada masyarakat desa Fakal sangat beragam. Keragaman tersebut dapat diuraikan sebagai berikut; struktur kalimat berdasarkan bentuk dan berdasarkan fungsi atau nilai komunikatifnya. Berdasarkan bentuknya, kalimat dapat diklasifikasi sebagai kalimat lengkap dan kalimat tak lengkap. Kalimat lengkap atau sempurna adalah kalimat yang tersusun dari subjek (S) dan predikat (P), baik disertai objek (O), pelengkap (Pel), dan keterangan (K). Kalimat lengkap dibedakan atas kalimat tunggal dan kalimat majemuk. 


\section{E. DAFTAR PUSTAKA}

Djajasudarma, T. Fatimah. 1999. Semantik I: Pengantar ke Arah Ilmu Makna. Bandung: Eresco

Kamus Besar Bahasa Indonesia. 2008. Edisi Keempat. Departemen

Pendidikan Nasional. Jakarta: Gramedia Pustaka Utama..

Kridalaksana, Harimurti. 2001. Pembentukan Kata dalam Bahasa Indonesia. Jakarta: Gramedia.

Miles, Matthew \& Michael Huberman. 2003. Analisis Data Kualitatif. Jakarta: UI Press.

Moleong, Lexy. 2010. Metedologi Penelitian Kualitatif (Edisi Baru). Bandung: Remaja Rosdakarya. 
